\title{
Comparison of Schools Participating Executives \& Parents of Students in the School Sports Olympiad Held in Mazandaran Province
}

\author{
Somaye Faghanpour ${ }^{1}$ and Mohammadbagher Forghani Ozrudi ${ }^{2 *}$ \\ ${ }^{1}$ Department of Sport management, Amol Bran $\neg$ ch, Iran \\ ${ }^{2}$ Young Researchers and Elite Club, Qaemshahr Branch, Iran
}

*Corresponding author: Mohammadbagher Forghani Ozrudi, Young Researchers and Elite Club, Qaemshahr Branch, Islamic Azad University, Qaemshahr, Iran

Submission: 眥 March 13, 2018; Published: 制 May 29, 2018

\begin{abstract}
The purpose of this study was to Comparison of schools participating executives \& parents of students in the School Sports Olympiad held in Mazandaran province. The research method was descriptive and survey research. The research population consists of all teachers of Physical Education (1593), respectively. According to Morgan random sample of three regions (East, Central and West), 310 were selected. The data collected through a questionnaire with a Likert scale was used Word. In this questionnaire, participants were asked to give their opinion about the involvement of interschool sports Olympiad held in three parts (opening and closing, during holding) stating. Its validity by 10 university professors were approved after a pre-test and reliability $\alpha=0.92$ was confirmed. Kolmogorov-Smirnov test for normality of data and hypotheses for analysis of variance (ANOVA), t-test at significant level of P $\leq 0.05$ \& was used SPSS22 statistical software. Analysis of the data shows that there is a significant difference between the involvement of school administration (principal and assistants) and parents of students in the School Sports Olympiad opening ceremony. There is a significant difference between the involvement of school administration (principal and assistants) and parents of students in the School Sports Olympiad held during the school year. There is a significant difference between the involvement of school administration (principal and assistants) and parents of students in the School Sports Olympiad held at the closing ceremony. There is a significant difference between the involvement of school administration (principal and assistants) in inter-school sports Olympiad held in the whole process (three stages). There is no significant difference between the students' parents to participate in inter-school sports Olympiad held in the whole process (three stages).
\end{abstract}

Keywords: Sports Olympiad; Fundamental transformation document; PE teacher

\section{Introduction}

Physical education lesson and sport is the most important part in schools educational programs and an instrument for supplying health, happiness and anxiety interaction and social training. [1]. Also, paying attention to physical education on schools has increased positive effect of this lesson on student's life [2]. Physical education lesson on Iran's' schools has experienced positive changes and many on educational curriculum, lesson plan content and supplying teacher by expertise [3]. These targets are related to requirements, experiences and persons' interest and determine targets and program direction according to the importance and developing eras of physical education science and its target is not limited to population class, but has been developed to all population classes [4].

Physical education as an influential factors and indispensable on health and social and cultural growth of people in society discussion, especially students has been paid attention by responsible and policy makers on education and training on the world and international organization's like UNESCO and UNICEF has been considered. Because participators on bodily activities as individual and group one learn how to comply with environment and people participated. And also from psych and bodily view discharge their selves. These factors along with other benefits of physical education has led country education system to instrumental use of this phenomenon on decreasing negative effect of using forming material, crime and antisocial behavior on school environment and on other hand strengthening manhood mood, respect to others, increasing self-confidence and participating on social activities by physical education along with giving identity to education and training through body in which is the same sweet lesson of physical education [5].

On the other hand, this social-cultural phenomenon does have stable relation to establishment's collections and social 
structures and should be paid attention as part of human structural requirements. One of the most important cause of development in developed countries is the tray of society structure to the important principle of physical education and generalizing it on different levels $[6,7]$. On recent decades, researchers has paid attention to the role of physical education and its importance on society as a fixed part of education and training and as an amusement and recreation has influenced society $[7,8]$. Also, they has paid attention to the amount of applivability of the resources on physical education and evaluated its performance [9].

Achieving to valuable targets of education and tratining on schools has been possible only through compelling systemic plan and targeted. Because on the procedure of executing these plans, we don't never forget learner training [10]. Physical education and schools sport is some part of educational experience and even life experience and the quality of this plan has been maintained by correct planning [11]. One of characteristic of physical education lesson in schools is using provided pattern, school teams' participation and parents on the games and giving rewards in which is required and guarantee success of executive plan on schools [2]. Study on other countries education and training shows most of countries by successful education and training, by developing extra-curricular activities, compensate education system weakness and has reached students' recreation time to the best way $[12,13]$.

Happiness and joy, friendly and ethical relation of students, students' sociability to schools, respect to self and other, personaland social taking responsibility, acceptance and respect to rule, bodily movement along with educational success and family expectation and education and training troubles are for achieving pure life beds [14]. Along operationally of the basic changes document on education and training system and concentrating on biological and bodily learning structures and also ethical and social of students (governmental school, non-governmental, Shahed, alight talents, exceptional, out of country schools and comparative)and according to the requirement of education and training justice and based on existing approaches on principle changes in education and training like 13-2,14-2, 16-1 on celebrating sport Olympiads in the schools has used of great capacity of schools as the most influential center for students presence and also general participation of managers, teachers, student's parents and other related organization's, has instituted spread movement on the past year [15].

Beliefs and recognitions students and parents does have from physical education and its plans, does have general share on developing and progress of physical education activities on schools. Whereas, these views and knowledge has been put on correct route and in service of general and dedicated targets of physical education, success and the influence of physical education lesson on schools has been guaranteed [16]. Researches has shown by participating extracurricular activities like physical education.....there should be so many benefits. Students who participate extracurricular activities, does have so many social adaptability $[17,18]$. Parents are the most important behavioral pattern in which like managers and teachers support students' activity on schools [3].

So many studies has shown positive relation among participation on extracurricular activities and self-confidence $[19,20]$. Participating on extracurricular activities increases mental health on youth $[21,22]$. Extracurricular activities on strengthening bodily dimension, sensational Social, national, aesthetics and spiritual of children does have very important role [1]. Recent research has shown participating extracurricular activities by the grounds of decreasing possibility of leaving education specially on high school, decreasing drug abuse and crimes, increasing inner personal competition and positive self-image and high mean and interaction to school, active participation on political procedure and other volunteered activities, mental health and hygiene are related on maturity [23]. The most part of recreational activities and extracurricular plan of students has been formed by sport games in and out of schools in which have been executed on the past years. Today's, inner school games, inner classes and among schools games has been executed as multi fields (sport Olympiads in and out of schools) and one filed (country students athletes) the first one by schools physical education teachers and the other by education and training ministry $[24,25]$.

Because executing this design is only on year experience and there is no research about examining executive factors of schools and students on country level, on the other hand, one of target in executing inner school sport Olympiads is establishing happiness and joy due to physical activities among students along with students having more relation to schools, developing people participation, employee participation and teacher's and parents to schools, recognizing sport talents and leading them to centers and expert stadium and regional Olympiads is another target in which inner school Olympiads has been executed. Therefore, researchers providing this topic in continue to compare the amount of executive factor's of schools and parents on executing sport Olympiads inner schools on Mazandaran province at last, research is to understand is there any differences among the amount of participation of executive factors of schools and parents on executing inner school sport Olympiads?

\section{Methodology}

Study according to target is applicable and has been done by descriptive measurement method. Required Statistical data for study has been gathered on field. Study statistical society according to the report of employment unit of education and training general office on Mazandaran on 2014-2015 includes 1517 teachers of physical education in which are working as formal, contractual, or promisingly. According to Morgan table, sample number for 1517 member society is 310 persons. Study data has been investigated by participation questionnaire on inner schools Olympiads by investigated questionnaire. Any question does have 5 choosers for answering. Tested provide their view about the amount of active factor participation and students' parent in which has cooperated 
with physical education teachers o different stages of inner school Olympiads. (Beginning, celebrating, completion) (50questions) and as Likert five choosers whereas selecting the first chooser does have 1 score and the second one having score2, and to five chooser having 5 svore to any question $(\alpha=0.92)$. Statistical data has been analyzed by t-test and for comparison among three stages of executing by ANOVA test has been analyzed. Accounting has been done by SPSS22 statistical software.

\section{Findings}

Table 1: The result of examining participation on sport Olympiads inner schools.

\begin{tabular}{|c|c|c|c|c|c|c|c|}
\hline \multicolumn{2}{|c|}{ Components } & Mean & SD & t & df & $\begin{array}{c}\text { Mean } \\
\text { differences }\end{array}$ & Sig. \\
\hline \multirow{2}{*}{ Opening } & $\begin{array}{c}\text { Schools participating } \\
\text { executives }\end{array}$ & 32.99 & 2.68 & 4.088 & 309 & 0.289 & 0.001 \\
\cline { 2 - 7 } Parents of students & 13.63 & 1.12 & & & 0.238 & 0.001 \\
\hline \multirow{2}{*}{ During holding } & $\begin{array}{c}\text { Schools participating } \\
\text { executives }\end{array}$ & 27.18 & 2.07 & 4.121 & 309 & 0.357 & 0.001 \\
\cline { 2 - 8 } & Parents of students & 11.26 & 1.31 & & 309 & & \\
\hline
\end{tabular}

The result show that $52.58 \%$ participator was men. The mean age of $42-36$ by $52.26 \%$ and the most frequency. Participator having bachelor degree $62.91 \%$ having the most frequency and the least mean is related to Ph.D. degree by $0.97 \%$ in which taste having physical education degree have has $94.51 \%$ and the most frequency. They has having service past record among 11 to 20 years by $33.55 \%$, the most frequency and also official employment status having $60 \%$ by the most frequency (Table 1 ).

Participator having sport past record by $60.97 \%$ having training past record by $68.39 \%$ and non-cooperating with university by $71.96 \%$ does have the most frequency. The mean executive factor participation of schools and students' parents on executing sport Olympiads inner schools on executing celebration and completion and also year's long does have meaningful differences (Table 2).

Table 2: The result of variance one-way test analysis for participating schools executive factors.

\begin{tabular}{|c|c|c|c|c|c|c|}
\hline Variable & Difference Place & SS & df & MS & F & P \\
\hline $\begin{array}{c}\text { Executive } \\
\text { involvement of } \\
\text { schools }\end{array}$ & Among groups & 844.9 & 2 & 422.4 & 0.001 \\
\hline & Inner groups & 564.2 & 308 & 13.4 & & \\
\hline & Total & 1409.2 & 310 & & & \\
\hline
\end{tabular}

One way variance analysis on Table 2 has shown there is meaningful differences among the mean of executive factors (manager and assistant) on celebrating sport Olympiads inner school on the whole procedure $(F(43.2)=31.44, p=0.001)$. The other word, hypothesis zero would be rejected. Therefore, in order to determine the resource of differences and testing sub hypothesis, we have used of Tokay- pursuit test (Table 3).
Table 3: the result of Tokay-pursuit test for participating schools executive factors.

\begin{tabular}{|c|c|c|}
\hline \multicolumn{2}{|c|}{ Groups } & Sig \\
\hline Opening & During holding & 0.001 \\
\hline & Closing & 0.645 \\
\hline Closing & During holding & 0.001 \\
\hline & Opening & 0.645 \\
\hline
\end{tabular}

Table 4: The result of one-way variance analysis for participating student parent.

\begin{tabular}{|c|c|c|c|c|c|c|}
\hline Variable & Difference Place & SS & df & MS & F & 1.08 \\
\hline $\begin{array}{c}\text { Parents of students } \\
\text { participating }\end{array}$ & Among groups & 2.8 & 2 & 1.4 & 0.349 \\
\hline & Inner groups & 54.4 & 308 & 1.29 & & \\
\hline & Total & 57.2 & 310 & & & \\
\hline
\end{tabular}

The result of Tokay-pursuit test has shown there are meaningful zero hypothesis has been rejected. On the other hand there is no differences among the mean participation of executive factors on meaningful difference among participating schools executive schools (12.13) and on the years long (2.40) ( $\mathrm{p}=0.001)$. Therefore, factors on the beginning and completion ( $\mathrm{p}=0.645)(\mathrm{Table} 4)$. 
The result of one way variance analysis on Table 4 has shown there is no meaningful differences among the mean participation of students parent on celebrating sport Olympiads inner schools on the whole of procedure(three stages $)(p=0.349 f(42,2)=1.08)$ in other words, zero hypothesis has been accepted.

\section{Discussion and Conclusion}

The result of examining hypothesis 1 has shown there is differences among the amount of participation of executive factors (manager and assistant) and students' parent on executing sport Olympiads inner schools on inaugural celebration. The result of this study is the same as researchers like Hajizadeh et al. [26], Nazari Alamdarloo et al. [27]. Hajizadeh et al. [26] has found youth participation on sport by parents' promotion, the same age group and friends and teachers and sport teachers has been done: one of these matters is inner school sport Olympiads Nazari Alamdarloo et al. [27] has indicated planning recreation time and families and social policy makers and hygiene should support physical education recreate time and culture making for putting physical education on people life style specially students and from participating physical activities.

According to execution of sport Olympiads inner schools on recreation time, extracurricular hours after lesson class or afternoon perhaps shows the low amount of parent participation due to having affairs and their presence on work place (public office and organization or free jobs) and also due to not dedicating budget from education and training ministry in which shows their tendency on participating on Olympiads. But time and official problems hinders parent presence on celebrating inaugural celebration The result of examining hypothesis 2 , it shows there is differences among the amount of participation of executive factors of schools (manager and assistant) and students parent on executing sport Olympiads celebration inner school on education yearlong .current study result is the same as Hozhabri et al. [28]. Hozhabri et al. [28] has found providing knowledge, descripting targets, plans and physical education lesson benefits for parents and providing calm environment and enjoyable without tension along with amusing activities and recreational and feasible to will and students' interest is necessary.

Schools executive factors presence on games due to forming workgroup on celebrating games by schools sport council and devolution authority to them is along with physical education teachers audit on the year. On the hand, according to the presence of schools executive factors as the whole time on schools and also the motivation for receiving promotion letter from city education and training office and general office of province based on participating schools sport Olympiads on the first year of celebrating by education and training ministry does have positive reflection among all member's of education and training office, and is the cause of presence of executive factors on the year ling as executor of sport Olympiad along with physical education teachers.

The result of third hypothesis has shown there are differences among the amount of participation of schools executive factors (manager and assistant) and students parent on celebrating Olympiads inner school on completion celebration. The result of study is the same as Talaei [29]. Talaei [29] has found lack of cooperation among organization's, teachers, families and students for executing design, lack of budget, not having compiled plan for future years after execution and on executing general design are of not being success factor of national sport design of students. According to executing guidance of inner school sport Olympiads based on presence of school manager, guest characters, all teachers and students, member of parent association, interested parent and executor on completion of inner school Olympiads, perhaps shows the difference among students parent participation due to lack of informing by schools executive factors, work affairs and lack of enough time for participating on completion celebration in which should be considered on another study.

The result of hypothesis 4 shows there is differences among participation amount of executive factors in schools (manager and assistant) on executing sport Olympiads inner school on the whole procedure. The result of current study is not the same as the result of researchers like Imamjom'e et al. [13], Dashti Joshghan [25], has found executing plans has been done by students and leading plans is on the shoulder of trainer or training assistant. Dashti Joshghan [25] has found lack of familiarity of executive factors to the method of spending recreation time decreases student participation on sport. According to the role of families and school managers on strengthening students mood and establishing joy on school environment through different method, also participation on sport designs like inner school sport Olympiads, camps, requires responsible follow up and general support and parents participation on establishing and developing health culture by the center of doing physical activities and physical education on students self are very important and should be followed continuously. The most important point for parents, schools responsible and specially physical education teachers is to increases student tendency to physical education positively.

The result of hypothesis 5 has shown there are no differences among the amount of participation of student's parent on celebrating sport Olympiads inner school on the whole procedure (three stages). The result of current study is the same as Yoosefy et al. [29], Hozhabri et al. [28], Imamjom'e et al [13], Eliasi [31], Dashti Joshghan [25], Morris et al. [32] result. Yoosefy et al. [30] has found parents more support is along with children's' more activity on physical education. Imamjom'e et al. [13] has found parents' participation on executing extracurricular activities is on low level. Hozhabri et al. [28] has required providing information, descripting targets, planed and benefit of physical education lesson for parents for participating on schools physical education plans. Eliasi [31] has found by increasing information and parents' participation on physical education plans, we could increase student's tendency to physical education lesson. Dashti Joshghan [25] has found establishing limitation from parents and lack of importance to the students recreation time decreases students participation on physical education. Morris et al. [32] has found plans based 
on usually activity is the basic danger for crimes and antisocial behavior including person, family, school, and the factor of target society. Observes has shown in order to use potential share of physical education and its plan on preventing or decreasing crimes and other antisocial behavior's, managers should mix all these indicators. Of the target of executing sport Olympiads in the schools is establishing volunteered movement for students and families' participation on physical education and developing it. According to the result from study, the participation of student's parent is on the low level and we should increase the motivation of parents for participation by exact planning.

\section{References}

1. Adams GN, Shea C (2008) Learning to teach a critical approach to field experiences, Mahwah, London, UK.

2. Ershad T, Arestani A, Azmoon J, Hallaji M, Mo'tamedi P, et al. (2013) Book of corporal correction sixth grade health teacher. Tehran: Directorate of the Ministry of Education textbook printing and distribution.

3. Ramezaninejad B, Abdimoghadam SA (2015) Compare the position of teaching physical education from the perspective of administrators, teachers, students parents in High school. Journal of Educational Physical Education 2(1): S61-S53.

4. Fathi S (2006) Study of social and cultural factors affecting the tendency to exercise in between athletes. Journal of Sociology 4: 104-173.

5. Habibnia Rami, S, Dousti M (2015) Identify challenges within the school Olympiad project: A Case Study of Mazandaran province. International Journal of Sport Studies 5(9): 1054-1058.

6. Talebpour M (2006) Develop a system of monitoring and evaluation of programs and activities in physical education and athletics in the country. According to research, Research Center of Physical Education and Sport Sciences.

7. Nikkhoo M, Mohammadi N, Barari AR (2015) Relationship indoor school sports Olympiad with achieve the objectives of fundamental transformation document Ministry of Education. International Journal of Sport Studies 5(7): 890-894.

8. Kalashi M, Hosseini SA, Ebrahimipour, Yamini Firoz M (2014) Clarifying the role of exercise in building a healthy society with an emphasis on reducing delinquency and consumption of tobacco products. Physical Education and Sports Sciences Association's first scientific and technical conference, Shahid Beheshti University, Tehran, Iran.

9. Hematinezhad M, Ramezaninezhad R (2009) Monitoring and evaluation in physical education and sports. Amol: Publications stable north.

10. Khavari L, Yousefian J (2009) Check the status of implementation of physical education in middle schools and high schools in Yazd province. Research in Sport Science 6(18): 87-100.

11. Sajjadi SA, Razavi SMH, Mohamadi A (2015) The compare of teacher viewpoints about the factors effecting on quality of physical education course. $8^{\text {th }}$ International Congress on Physical Education \& Sport Sciences. Teharn, Iran.

12. Fathabadi MB (2004) Necessary and how to create extra-curricular activities point of view of students, parents and high school coaches in Markazi Province. Research projects, the Research Council of the Markazi provincial education.

13. Imamjom'e SM, Ahmadi G, Teymournia M (2013) A comparative study of extracurricular activities in primary schools of Iran, America, England, and Malaysia. Journal of curriculum research 3(1): 17-65.
14. Torabi A (2015) Families and inter-school sports Olympiad. Weekly Neghah 20(516): 1.

15. Ministry of Education (2015) Instructions second inter-school sports Olympiad. Physical Education Department of the Ministry of Education.

16. West A, Boucher A (2011) Foundations of physical education and sport, luminous knowledge, Tehran, Iran.

17. Barati A, Zandi P (2001) The effect of extra-curricular activities on student achievement. Department of Education of Tehran Research Council, the research project.

18. Smitht PH (2007) The relationship between scores on the Bell Adjustment Inventory and participation in extra-curricular activities. J Educ Psychol 38(1): 11-16.

19. Farhadi S, (2005) The effect of student council activities Brzt esteem and responsibility of middle school students in the city of Karaj. Master's thesis.

20. Kazemi M (2000) The effect of extracurricular activities on the responsibility of girls and boys high school students in Damavand city. Senior thesis, Islamic Azad University, Roodehen Branch, Iran.

21. Meyers J, Perez L (2004) Structured extracurricular activities among adolescents. University of Kentucky, USA.

22. Kerr B (2009) Encyclopedia of giftedness, creativity, and talent. A SAGE Reference Publication.

23. Pkins SS (2008) Non-scchool curriculum supporting positive development through structured activities. SAGE Publication.

24. Amirtash AM (2001) Description and evaluation of the country's fifthSport Olympiad students, research report, Institute of Physical Education and Sport Sciences, Ministry of Science, Research and Technology.

25. Dashti Joshaghan H (2000) Compare the spending leisure time of students and its related issues from the perspective of parents of middle school students Mashhad 6 region. Master's Thesis, Ferdowsi University of Mashhad.

26. Hajizadeh S, Naderian Jahromy M, Soleimani M (2015) Students prioritize social determinants of sports participation. Fourth National Conference on Student Sports Sciences, Shahid Beheshti University, Tehran, Iran.

27. Nazari Alamdarloo N, Niromand S, Ghafori F (2014) The role of leisure sports activities in abnormal behaviors in Tehran high school students. Physical Education and Sports Sciences Association's first scientific and technical conference, Shahid Beheshti University, Tehran, Iran.

28. Hozhabri K, Ramezaninezhad R, Hematinezhad M (2014) Survey of physical education lesson preferences among secondary school courses. Sport Management \& Development 2(2): 73-89.

29. Talaei A (2015) Identify barriers to implementation of national plans for sport in schools in Mazandaran province. Thesis Master of Physical Education, Islamic Azad University, Sari Branch, Iran.

30. Yoosefy B, Azimirad J, Malekian A (2014) Relationship between parenting styles and sport participation of teenager girl students. Sport Psychology Studies 3(9): 66-55.

31. Eliasi H (2011) Practices increase students' inclination towards physical education and improve the quality of physical education lessons in schools for boys Kohgiluyeh and Boyer tips. Master's thesis. Payam Noor university of Tehran.

32. Morris L, Sallybanks J, Willis K (2003) Sport, physical activity and antisocial behaviour in youth, Research and Public Policy Series, no. 49, Australian Institute of Criminology, Canberra, USA. 
Creative Commons Attribution 4.0 International License

For possible submissions Click Here

Submit Article
RISM $1=$

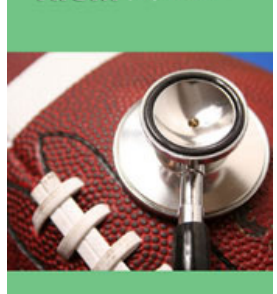

Research \& Investigations in Sports Medicine

\section{Benefits of Publishing with us}

- High-level peer review and editorial services

- Freely accessible online immediately upon publication

- Authors retain the copyright to their work

- Licensing it under a Creative Commons license

- Visibility through different online platforms 